\title{
Prevalence Of Methicillin-Resistant Staphylococci Among Apparently Healthy Students Attending A Tertiary Institution In Benin City, Nigeria
}

\author{
${ }^{*}{ }^{1} H$. O. Ogefere, ${ }^{1}$ G. Umaru, ${ }^{2}$ E. E. Ibadin and ${ }^{2,3}$ R. Omoregie \\ 1Department of Medical Laboratory Science, School of Basic Medical Sciences, University of Benin, Benin City, Edo State, Nigeria \\ ${ }^{2}$ Medical Microbiology Unit, Medical Laboratory Services, University of Benin Teaching Hospital, Benin City, Nigeria \\ ${ }^{3}$ School of Medical Laboratory Science, University of Benin Teaching Hospital, Benin City, Nigeria \\ [ ${ }^{\star}$ Corresponding Author: E-mail: helenogefere@yahoo.com]
}

\section{ABSTRACT}

This study was aimed at determining the prevalence of methicillin resistant Staphylococcus aureus (MRSA) and methicillin resistant coagulase negative staphylococci (MRCoNS) among apparently healthy students of a tertiary institution in Benin City, Nigeria. A total of 350 students were recruited for the study and nasal swabs were collected alongside demographic data. These swabs were processed microbiologically using standard techniques to recover staphylococci. Antimicrobial susceptibility and methicillin-resistance was determined using a phenotypic method (cefoxitin resistance). A total of $148(42.3 \%)$ of 350 students were culture positive for S. aureus, while $72(20.6 \%)$ were positive for CoNS. Students from Faculty of Dentistry showed the highest prevalence of nasal MRSA (40.0\%) and MRCoNS $(20.0 \%)$. Ofloxacin and gentamicin were the most active antibacterial agents against MRSA with $89.1 \%$ and $87.3 \%$ respectively been susceptible, while gentamicin was the most active antibiotic against MRCoNS (75.0\%). Nasal colonization by MRSA and MRCoNS was unaffected by area of residence and gender $(P>0.05)$. The nasal carriage rate of MRSA and MRCoNS was $37.2 \%$ and $33.3 \%$ respectively. The study recommends periodic review of nasal colonization rates among apparently healthy subjects. Regulated use of antimicrobial agents is imperative in order to stem the tide of resistance.

Keywords: Methicillin-resistance, Staphylococci, Students, Antibiotics

\section{INTRODUCTION}

Since the first detection of methicillin-resistance in Staphylococcus aureus in 1961, the worldwide prevalence of MRSA being implicated in hospital and community-acquired infection has been on the rise (Olowe et al., 2013). Coagulase-negative staphylococci (CoNS) belong to normal microbial flora of the skin and mucous membranes (Azih and Enabulele, 2013). These organisms have relatively low virulence but are increasingly recognized as agents of clinically significant infection of the bloodstream and other sites (Azih and Enabulele, 2013). The incidence of methicillin-resistant CoNS (MRCoNS) causing infection are now on the rise and have equally been implicated in clinical infections worldwide (Ibadin et al., 2017).

The association between $S$ aureus nasal carriage and staphylococcal disease was first reported in 1931 (Solberg, 1965; Sollid et al., 2014). Due to an increase in staphylococcal infection, subsequent studies which investigated a causal relationship between nasal carriage of $S$ aureus and infection was proven by the fact that the nasal $S$ aureus strain and the infecting strain shared the same phage type or genotype (von Eiff et al., 2001; Sollid et al., 2014). CoNS have also increasingly drawn attention as nasal carriage has been shown in recent studies (Abadi et al., 2015).

The specific mechanism of resistance to methicillin/oxacillin in staphylococci is due to expression of mecA gene (lto et al., 1999). mecA gene codes for penicillin binding protein $2 a$ (PBP2a), a transpeptidase with low affinity for $\beta$ lactams which confers resistance to methicillin and other $\beta$-lactam antibiotics in staphylococci harboring the gene (Ito et al., 1999). Methicillinresistant staphylococci are therefore typically 
difficult to treat owing to resistance that is shown to different antibacterial drugs.

Though molecular methods have emerged as the gold standard for detecting methicillin resistance in staphylococci, phenotypic methods have also proven reliable though differing sensitivities and specificities subsist in several studies (Olowe et al., 2013; Ibadin et al., 2017). The use of cefoxitin antibacterial as a surrogate marker for methicilin resistance is however very reliable when employed in agar dilution, broth micro-dilution or disc diffusion techniques (CLSI, 2013).

Methicillin-resistant staphylococci have been shown to be prevalent in health institutions, causing a wide range of clinical infections across Nigeria (Olowe et al., 2013; Ibadin et al., 2017). Efforts are now increasingly being made to explore the carrier status of healthcare workers (Rongpharpi et al., 2013), patients (von Eiff et al., 2001), apparently healthy individuals and companion animals in order to ascertain their role in transmission (Okodua et al., 2013). This study was however aimed at determining nasal carriage of MRSA and MRCoNS among apparently healthy students in a tertiary institution in Benin City, Nigeria.

\section{MATERIALS AND METHODS}

\section{Study Population}

A total of 350 apparently healthy students who had not taken antibiotics in the last one month were recruited for this study. These were students from various Faculties of the University of Benin, Benin City, Nigeria.

\section{Sample Collection and Processing}

Nasal swab was collected from all participants. Demographic data such as: Faculty of the student, gender, age, level, on-campus and offcampus residence. The nasal swabs from all participants were inoculated on $3 \% \mathrm{NaCl}$ nutrient agar. The plates were incubated aerobically for $24 \mathrm{~h}$ at $37^{\circ} \mathrm{C}$.

\section{Bacterial Isolates}

Emergent bacterial isolates from culture plates were identified following Gram stain and appropriate biochemical tests namely catalase, coagulase (slide and/or tube), citrate utilization, indole, gelatin hydrolysis, Vogues-Proskauer, sucrose, maltose, lactose and glucose as described in standard Medical Microbiology laboratory manual (Cheesbrough, 2009). All Staphylococcus spp recovered were thereafter stored at $4^{\circ} \mathrm{C}$ on Mueller Hinton agar slants for further work.

\section{Susceptibility Testing}

Antimicrobial susceptibility testing was carried out following the recommendation of British Society for Antimicrobial Chemotherapy (BSAC) method (Andrew, 2009). The test colonies were emulsified in sterile distilled water and the turbidity matched with $0.5 \mathrm{McF}$ arland. Once matched, a sterile cotton wool swab was dipped in the organism suspension and excess liquid was removed by turning the swab on side of the test tube. The entire surface of Mueller-Hinton agar plate was seeded by swabbing in three directions with the swab. The antibiotic discs were placed on the plate with the use of a sterile forceps. The antibiotics used include the

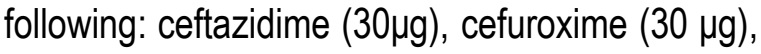
ceftriaxone $(30 \mu \mathrm{g})$, Cloxacillin $(5 \mu \mathrm{g})$, amoxicillinclavulanate $(30 \mu \mathrm{g})$, erythromycin $(5 \mu \mathrm{g})$, ofloxacin $(5 \mu \mathrm{g})$, gentamicin $(10 \mu \mathrm{g})$ (all from Abtek U.K).

\section{Screening for methicillin-resistance}

All Staphylococcus spp isolated were screened for methicillin-resistance by following CLSI guidelines using $30 \mu \mathrm{g}$ cefoxitin discs (Abtek U.K) (CLSI, 2013). Plates were read after incubation at $35^{\circ} \mathrm{C}$ for $18 \mathrm{~h}$. Zone diameter $\leq 21 \mathrm{~mm}$ was deemed cefoxitin resistant.

\section{Statistical Analysis}

The frequency data were compared using the chi square $\left(X^{2}\right)$ test. The statistical software INSTAT ${ }^{\circledR}$ was used for the analysis. A $p$ value of $<0.05$ was deemed statistically significant. 
RESULTS

A total of 350 apparently healthy students were recruited for this study. Of this number, 148 $(42.3 \%)$ of students were culture positive for $S$. aureus, while $72(20.6 \%)$ were positive for CoNS. The prevalence of $S$. aureus and CoNS were significantly higher among students of the Faculties of Dentistry $(p=0.0118)$ and Medicine $(p=0.0113)$ respectively, compared to students from other Faculties (Table 1).

The nasal carriage rate of MRSA and MRCoNS among apparently healthy students in this study was $37.2 \%$ and $33.3 \%$ respectively. The prevalence of MRSA and MRCoNS were not significantly different $(p>0.05)$ and were not affected by students Faculty ( $p>0.05$ ) (Table 2). Similarly, gender of students and location of their residence did not significantly ( $p>0.05)$ affect the prevalence of MRSA and MRCoNS (Table 3).

Gentamicin and ofloxacin were the most active antibacterial agents against MRSA, MSSA MRCoNS and MSCoNS (Tables 4 and 5) with MRSA isolates been significantly $(p<0.0001)$ more susceptible to gentamicin and ofloxacin than MSSA isolates (Table 4). MSCoNS isolates were significantly $(p=0.0312)$ more susceptible to cefuroxime than their MRCoNS counterparts (Table 5). Generally, the susceptibilities of all isolates to the other tested antibacterial agents were poor.

Table 1: Distribution of staphylococci according to different faculties

\begin{tabular}{|c|c|c|c|}
\hline Faculty & $\begin{array}{l}\text { Number of students } \\
\text { tested }\end{array}$ & Staphyhlococcus aureus & CoNS \\
\hline $\begin{array}{ll}\text { Basic } & \text { medical } \\
\text { sciences } & \end{array}$ & 100 & $58(58.0)$ & $16(16.0)$ \\
\hline $\begin{array}{l}\text { Management } \\
\text { sciences }\end{array}$ & 14 & $7(50.0)$ & $2(14.3)$ \\
\hline Art & 34 & $8(23.5)$ & $3(8.8)$ \\
\hline Pharmacy & 18 & $8(44.4)$ & $2(11.1)$ \\
\hline Agricultural sciences & 24 & $6(25.0)$ & $9(37.5)$ \\
\hline Physical sciences & 14 & $6(42.9)$ & $2(14.3)$ \\
\hline Engineering & 11 & $2(18.2)$ & $1(9.1)$ \\
\hline Dentistry & 5 & $3(60.0)$ & 0 \\
\hline Medicine & 26 & $10(38.5)$ & $12(46.2)$ \\
\hline Law & 9 & $1(11.1)$ & $1(11.1)$ \\
\hline Education & 24 & $11(45.8)$ & $4(16.7)$ \\
\hline Life sciences & 36 & $14(38.9)$ & $10(27.8)$ \\
\hline Social sciences & 35 & $14(40.0)$ & $10(28.6)$ \\
\hline TOTAL & 350 & $148(42.3)$ & $72(20.6)$ \\
\hline
\end{tabular}

Staphylococcus aureus: $p=0.0118$; CoNS: $p=0.0113$, CoNS- Coagulase negative staphylococci, number in brackets $=$ value in percentage. 
Nigerian Journal of Basic and Applied Science (June, 2019), 27(1): 114-121

Table 2: Distribution of methicillin-resistant staphycococci among students from different faculties.

\begin{tabular}{|c|c|c|c|c|c|}
\hline \multirow{2}{*}{ Faculty } & \multicolumn{2}{|c|}{$\begin{array}{l}\text { Staphylococcus } \\
\text { aureus }\end{array}$} & \multicolumn{2}{|l|}{ CoNS } & \multirow{2}{*}{$P$ value } \\
\hline & $\begin{array}{l}\text { No. } \\
\text { tested }\end{array}$ & MRSA & $\begin{array}{l}\text { No. } \\
\text { tested }\end{array}$ & MRCoNS & \\
\hline $\begin{array}{l}\text { Basic Medical } \\
\text { Sciences }\end{array}$ & 58 & $24(43.6)$ & 16 & $5(31.3)$ & 0.5691 \\
\hline $\begin{array}{l}\text { Management } \\
\text { Sciences }\end{array}$ & 7 & $3(42.9)$ & 2 & $1(50.0)$ & 1 \\
\hline Art & 8 & $2(25.0)$ & 3 & $1(33.3)$ & 1 \\
\hline Pharmacy & 8 & $4(50.0)$ & 2 & $1(50.0)$ & 1 \\
\hline $\begin{array}{l}\text { Agricultural } \\
\text { sciences }\end{array}$ & 6 & $2(33.3)$ & 9 & $3(33.3)$ & 1 \\
\hline $\begin{array}{l}\text { Physical } \\
\text { Sciences }\end{array}$ & 6 & $3(50.0)$ & 2 & $1(50.0)$ & 1 \\
\hline Engineering & 2 & 0 & 1 & $1(100.0)$ & 1 \\
\hline Dentistry & 3 & $2(66.7)$ & 0 & 0 & ND \\
\hline Medicine & 10 & $4(40.0)$ & 12 & $5(41.7)$ & 1 \\
\hline Law & 1 & 0 & 1 & $1(100.0)$ & \\
\hline Education & 11 & $3(27.3)$ & 4 & $1(25.0)$ & 1 \\
\hline Life Sciences & 14 & $3(21.4)$ & 10 & $3(30.0)$ & 0.6653 \\
\hline $\begin{array}{l}\text { Social } \\
\text { Sciences }\end{array}$ & 14 & $5(35.7)$ & 10 & $2(20.0)$ & 0.6529 \\
\hline TOTAL & 148 & 55 (37.2) & 72 & $24(33.3)$ & 0.685 \\
\hline
\end{tabular}

MRSA vs Faculty: $p=0.8926$; MRCoNs vs Faculty: $p=0.8595$, MRCoNS-Methicillin resistant coagulase negative staphylococci, MRSA-Methicillin resistant Staphylococcus aureus, CoNS- Coagulase negative staphylococci, ND- Not done, number in brackets $=$ value in percentage 
Table 3: Prevalence of methicillin-resistant Staphylococcus aureus and Coagulase negative staphylococci among students in relation to area of residence and Gender

\begin{tabular}{llll}
\hline & $\begin{array}{c}\text { Number of isolates } \\
\text { tested }\end{array}$ & Methicillin-Resistant(\%) & $p$ value \\
\hline $\begin{array}{l}\text { Residence } \\
\text { S. aureus }\end{array}$ & & & 0.3956 \\
On- Campus & 100 & $40(40.0)$ & \\
Off- Campus & 48 & $15(31.3)$ & \\
CoNS & & & 0.7998 \\
On-campus & 42 & $15(35.7)$ & \\
Off-campus & 30 & $9(30.0)$ & \\
Gender & & & 0.1305 \\
S. aureus & & $16(28.6)$ & \\
Male & 56 & $39(42.4)$ & \\
Female & 92 & $13(38.2)$ & \\
CoNS & & $11(28.9)$ & \\
Male & 34 & CoNS-Coagulase negative staphylococci & \\
Female & 38 & &
\end{tabular}

Table 4: Antimicrobial susceptibility pattern of Staphylococcus aureus isolates recovered from apparently healthy students

\begin{tabular}{|c|c|c|c|}
\hline $\begin{array}{l}\text { Antibacterial } \\
\text { drugs }\end{array}$ & MRSA (\%) n = 55 & $\begin{array}{l}\text { MSSA } \\
(\%) n= \\
93\end{array}$ & $\mathrm{p}$ \\
\hline Cloxacillin $(5 \mu \mathrm{g})$ & $1(1.8)$ & $3(3.2)$ & 0.6098 \\
\hline Erythromicin $(5 \mu \mathrm{g})$ & $29(52.7)$ & $33(35.5)$ & 0.0598 \\
\hline Gentamicin $(10 \mu \mathrm{g})$ & 49 (89.1) & $37(39.8)$ & $<0.0001$ \\
\hline $\begin{array}{l}\text { Amoxicillin-clavulanate } \\
(30 \mu \mathrm{g})\end{array}$ & $1(1.8)$ & $6(6.45)$ & 0.3775 \\
\hline Ofloxacin $(5 \mu \mathrm{g})$ & $48(87.3)$ & $40(43.0)$ & $<0.0001$ \\
\hline Ceftazidime (30 $\mu \mathrm{g})$ & $4(7.3)$ & $11(11.8)$ & 0.5448 \\
\hline Cefuroxime (30 $\mu \mathrm{g})$ & $3(5.5)$ & $10(10.8)$ & 0.4238 \\
\hline Ceftriaxone $(30 \mu \mathrm{g})$ & $3(5.5)$ & $13(14.0)$ & 0.097 \\
\hline
\end{tabular}

MRSA-Methicillin resistant Staphylococcus aureus, MSSA- Methicillin susceptible $S$. aureus, $n=$ number of isolates tested 
Table 5: Antimicrobial susceptibility of Coagulase negative staphylococci

\begin{tabular}{llll}
\hline Antibacterial drugs & $\begin{array}{l}\text { MRCoNS } \\
(\%)\end{array}$ & $\begin{array}{l}\text { MSCoNS } \\
(\%)\end{array}$ & $p$ \\
\cline { 2 - 3 } & $\mathrm{n}=24$ & $\mathrm{n}=48$ & \\
\hline Cloxacillin $(5 \mu \mathrm{g})$ & $0(0)$ & $9(18.8)$ & 0.0588 \\
Erythromycin $(5 \mu \mathrm{g})$ & $8(33.3)$ & $20(41.7)$ & 0.6691 \\
Gentamicin $(10 \mu \mathrm{g})$ & $18(75.0)$ & $23(47.9)$ & 0.0529 \\
Amoxicillin- & $1(4.2)$ & $7(14.6)$ & 0.3534 \\
clavulanate $(30 \mu \mathrm{g})$ & & & \\
Ofloxacin $(5 \mu \mathrm{g})$ & $14(58.3)$ & $22(45.8)$ & 0.4533 \\
Ceftazidime $(30 \mu \mathrm{g})$ & $2(8.3)$ & $10(20.8)$ & 0.3134 \\
Cefuroxime $(30 \mu \mathrm{g})$ & $1(4.2)$ & $14(29.2)$ & 0.0312 \\
Ceftriaxone $(30 \mu \mathrm{g})$ & $3(12.5)$ & $11(22.9)$ & 0.4611 \\
\hline
\end{tabular}

MRCoNS- Methicillin resistant coagulase negative staphylococci, MSCoNS- Methicillin susceptible coagulase negative staphylococci, $n=$ number of isolates tested

\section{DISCUSSION}

The ecological niche for $S$. aureus has long been identified as the anterior nares in man (Sollid et al., 2014). The carriage rate varies from one geographical location to another (14). Several studies have in recent times shown nasal carriage for CoNS (Abadi et al., 2015).

In this study, the carriage rate of $S$. aureus and CoNS was 42.3 and $20.6 \%$ respectively among apparently healthy students. The carriage rate of $S$. aureus observed is slightly higher than a similar study in Ekpoma, Edo state which reported $35.4 \%$ among apparently healthy residents of the town (Okodua et al., 2013). The carriage rate is equally higher than another study in Thailand which evaluated nasal swabs of medical students, where a colonization rate of $29.7 \%, 30.5 \%$ and $39.4 \%$ respectively was observed for $S$. aureus when screened thrice (Treesirichod et al., 2014). The nasal colonzation rate of CoNS was comparatively lower than $S$. aureus in this study and approximately half the rate observed for $S$. aureus. This finding differs strikingly from an Iranian study among students where nasal colonization rate was reported as $71.1 \%$ (Abadi et al., 2015). A carriage rate of $6.25 \%$ had been earlier reported among hospital personnel and students in lle-lfe (Shittu et al., 2006). Our study therefore shows an increase in nasal colonization of CoNS in comparison with a previous study in Southern Nigeria.

Methicillin-resistance in staphylococci is strongly associated with resistance to beta-lactam antibiotics (Abadi et al., 2015; Ibadin et al., 2017). This includes an array of antibiotics namely penicillin, cephalosporins and carbapenems. The 
nasal colonization rate of MRSA and MRCoNS among students in this study was $37.2 \%$ and $33.3 \%$ respectively. Previous studies have demonstrated a causal link between nasal carriage of staphylococci and subsequent infection (von Eiff et al., 2001). Several researchers have also shown a relationship between nasal carriage of staphylococci among healthcare workers and an outbreak of MRSA in wards (Belani et al., 1986). Our study however observed a comparatively higher carriage rate among students of medicine, dentistry and other health professions in comparison with other Faculties. Though reasons may not be very clear, these students usually have compulsory postings in the hospital, thereby increasing their risk of exposure to these resistant bacterial strains among patients, hospital items, and specimens. A recent study showed a high prevalence of MRSA and MRCoNS among clinical specimens in the teaching hospital of University of Benin (Ibadin et al., 2017). A previous study in Thailand which evaluated carriage rate of $S$. aureus among students in preclinical classes by collecting nasal swabs prior to working in the hospital (the first), following the first rotation (the second) and at the end of the rotation schedule in the hospital (the last) observed an increasing carriage rate of $29.7 \%, \quad 30.5 \%$ and $39.4 \%$, respectively (Treesirichod et al., 2014). This may explain the higher prevalence observed among medical and dental students in this study.

In this study, students who resided on-campus had higher prevalence of MRSA and MRCoNS. The difference was however statistically insignificant in comparison with students residing off-campus. The finding was not too surprising as both groups are community dwellers with similar living conditions. Similarly, the difference between the nasal colonization of MRSA and MRCoNS for males and females was not statistically significant. The finding agrees with several previous studies (Okodua et al., 2013; Abadi et al., 2015; Ayepola et al., 2018).
MRSA showed poor susceptibility to most antibacterial agents tested in this study. Gentamicin and ofloxacin were however the most active antibacterial agents against MRSA and showed statistical significance in comparison with MSSA. The susceptibility profile of MRSA to gentamicin in this study is similar to another in Ekpoma which observed $100 \%$ susceptibility of MRSA to gentamicin (Okodua et al., 2013). In that study however, $100 \%$ susceptibility was observed for MSSA to gentamicin unlike this study where $39.8 \%$ was observed. MSSA were equally resistant to several other antibiotics tested. Antibiotic abuse is rife in our environment as has been previously stated (Ibadin et al., 2017). Similarly, MRCoNS and MSCoNS showed poor acitivity to the antibacterial agents tested. Gentamicin was however the most active antibiotic with $75 \%$ of MRCoNS being susceptible while MSCoNS were poorly susceptible. The finding compares with an Iranian study which reported $100 \%$ efficacy for gentamicin against nasal CoNs from students in which several SCCmec types were detected (Abadi et al., 2015). The observation that most MSCoNS were resistant to other antibacterial agents may imply that some other mechanism of resistance may be at play and poses potential health risk to carriers should such strain be implicated in opportunistic infection. Abuse of antibiotics can serve to create selective pressure, ensuring the survival of resistant bacterial strains (Ayepola et al., 2018).

\section{CONCLUSION}

The prevalence of nasal MRSA and MRCoNS in this study was $37.2 \%$ and $33.3 \%$ respectively. Gentamicin was the most effective antibiotic against methicillin resistant staphylococci. Regulated use of antimicrobial agents is imperative in order to stem the tide of resistance.

\section{REFERENCES}

Abadi, M.I.M., Moniri, R., Khorshidi, A., Piroozmand, A., Mousavi, S.G.A., Dastehgoli, K. and Ghazikalayeh, H.M. (2015). Molecular characteristics of nasal carriage methicillin-resistant coagulase 


\section{Nigerian Journal of Basic and Applied Science (June, 2019), 27(1): 114-121}

negative staphylococci in school students. Jundishapur Journal of Microbiology, 8(6): e18591

Andrew, J.M. (2009). BSAC standardized disc susceptibility testing method (version 3). Journal of Antimicrobial Chemotherapy, 53:713 - 728 .

Ayepola, 0.0., Taiwo, O.S., Anifowose, A. and Onile-ere, O. (2018). Nasal carriage of Staphylococcus aureus and associated risk factors among students in a Nigerian University. Acta Scientific Microbiology, 1(2): 06-08.

Azih, A. and Enabulele, I. (2013). Species distribution and virulence factors of coagulase negative staphylococci isolated from clinical samples from the University of Benin Teaching Hospital, Edo State, Nigeria. Journal of Natural Sciences Research, 3(9): 38 - 43.

Belani, A., Sherertz, R., Sullivan, M., Russell, B. and Reumen, P. (1986). Outbreak of staphylococcal infection in two hospital nurseries traced to a single nasal carrier. Infection Control, 7(10): 487-490.

Cheesbrough, M. (2009): District Laboratory Practice in Tropical Countries Part 2, Cambridge University Press, Cambridge.

Clinical Laboratory Standards Institute (2013). Performance standards for antimicrobial susceptibility testing M100S. Clinical and Laboratory Standards Institute, Wayne, PA; M100 pp 77

Ibadin, E.E., Enabulele, I.O. and Muinah, F. (2017). Prevalence of $m e c A$ gene among staphylococci from clinical samples of a tertiary hospital in Benin City, Nigeria. African Health Sciences, 17(4): 1000 1010.

Ito, T., Katayama, Y. and Hiramatsu, K. (1999). Cloning and nucleotide sequence determination of the entire mec DNA of pre-methicillin-resistant Staphylococcus aureus N315. Antimicrobial Agents Chemotheraphy; 43:1449 - 58

Okodua, M., Ebhodaghe, E.E., Turay, A.A., Adeleke, G. and ljiekhuamen, M. (2013). Relationship between some selected socio demographic profiles and methicillin- resistant Staphylococcus aureus among apparently healthy residents in Ekpoma, Nigeria. International Journal of Community Research, 2(1): 8-12.

Olowe, O.A., Kukoyi, O.O., Taiwo, S.S., Ojurongbe, O., Opaleye, O.O., Bolaji, O.O., Adegoke, A.A., Makanjuola, O.B., Ogbolu, D.O. and Alli, O.A. (2013). Phenotypic and molecular characteristics of methicillin-resistant Staphylococcus aureus isolates from Ekiti state, Nigeria. Infection and Drug Resistance, 6: 87-92.

Rongpharpi, R.S., Hazarika, N.K. and Kalita, H. (2013). The prevalence of nasal carriage of Staphylococcus aureus among healthcare workers at a tertiary care hospital in Assam with special reference to MRSA. Journal of Clinical and Diagnostic Research, 7(2): 257-260.

Shittu, A., Lin, J., Morrison, D. and Kolawole, D. (2006). Identification and molecular characterization of mannitol salt positive, coagulase-negative staphylococci from nasal samples of medical personnel and students Journal of Medical Microbiology, 55(3):317 - 324

Solberg, C.O. (1965). A study of carriers of Staphylococcus aureus with special regard to quantitative bacterial estimations. Acta Medica Scandinavica Supplementum, 436: 1-96.

Sollid, J.U.E., Furberg, A.S., Hanssen, A.M. and Johannessen, M. (2014). Staphylococcus aureus: determinants of human carriage. Infection, Genetics and Evolution, 21: 531541

Treesirichod, A., Hantagool, S. and Prommalikit, 0. (2014). Nasal carriage and antimicrobial susceptibility of Staphylococcus aureus among medical students at the $\mathrm{HRH}$ Princess Maha Chakri Sirindhorn Medical Center, Thailand: a follow-up study. Journal of Infection and Public Health, 7: 205 - 209.

von Eiff, C., Becker, K., Machka, K., Stammer, H. and Peters, G. (2001). Nasal carriage as a source of Staphylococcus aureus bacteremia. New England Journal of Medicine, 344: 11-16. 